\title{
Prediction of the Porosity of Al Alloys
}

Marek Brůna, Lukáš Kucharčík

Department of technological engineering, University Of Žilina, Univerzitná 1, 01001 Žilina, Slovak Republic, marek.bruna@fstroj.uniza.sk

The main goal of the research presented in this paper is to gain a deeper understanding of solidification processes in terms of porosity formation in AlSi7Cu0.5Mg alloy through complex data evaluation obtained from thermal analysis, simulation software ProCAST and also from real melts. Formation of porosity (micro, macro porosity) was examined under different casting conditions, the pouring temperature varied from $730{ }^{\circ} \mathrm{C}$ to $650{ }^{\circ} \mathrm{C}$. The experiment will attempt to analyze, how the pouring temperature effects the formation and character of porosity. For this purpose was various methods were used, not only real castings evaluation, but also advanced porosity module integrated into simulation software ProCAST. Experiments also try to compare simulation results with real conditions, to determine software abilities and accuracy. Specific casting and mold were designed to be able to observe porosity formation.

Keywords: simulation, thermal analysis, porosity, aluminum alloys

\section{Acknowledgements}

This work was created within the solution of the grant project KEGA. 006-ŽU-4/2012. The authors thanks the Grant Agency for support.

\section{References}

[1] MEDLEN, D., BOLIBRUCHOVÁ, D. (2012) The influence of remelting on the properties of AlSi6Cu4 alloy modi-fied by antimony. In: Archives of foundry Engineering, January-march, pp. 81-86, vol. 12, ISSN 18973310.

[2] KANTORÍK, R., BOLIBRUCHOVÁ, D. (2011). Free melt surface monitoring with the help of metal flow simulation in moulds. In: International Foundry Research, 2011, vol. 63, issue 2, pp. 18 - 23, ISSN 0046-5933.

[3] SLÁDEK, A., BOLIBRUCHOVÁ, D., PASTIRČÁK, R., VAŠKO, I. (2010). The influence of antimony on the properties of AlSi7Mg0.3 alloy. In: Proceedings of 69th world foundry congress: Hangzhou China. Pp 261 266.

[4] WEISS, V., STRIHAVKOVA, E. (2012). Influence of the homogenization annealing on microstructure and mechanical properties of AlZn5.5Mg2.5Cu1.5 alloy. In: Manufacturing Technology, Volume 12, pp. 297 - 302. ISSN 1213-2489.

[5] MICHALCOVÁ, A., VOJTECH, D. (2012). Structure of rapidly solidified aluminium alloys. In: Manufacturing Technology, Volume 12, pp. 166 - 169. ISSN 1213-2489.

[6] MACKAY, R. I., DJURDJEVIC, M. B., SOKOŁOWSKI, J. H. (2000) Effect of cooling rate on fraction solid of metallurgical reactions in 319 alloy. AFS Trans.00-25:521-30.

[7] MAJID KARIMIAN, ALI OURDJINI, MOHD HASBULLAH IDRIS, M. BSHER, A. ASMAEL (2011). "Effect of Pouring Temperature and Melt Treatment on Microstructure of Lost Foam Casting of Al-Si LM6 Alloy". Advanced Materials Research .264 - 265.

[8] S. SHIVKUMAR (1994). Modeling of Temperature Losses in Liquid Metal during Casting Formation in Expendable Pattern Casting Process. Materials Science and Technology, 10 986-992

[9] TILlOVÁ, E., CHALUPOVÁ, M., HURTAlOVÁ, L., ĎURNíKOVÁ, E. (2011). Quality control of microstructure in recycled Al-Si cast alloys. In Manufacturing Technology, Vol. 11, No. 11, p. 70-76

[10] BRŮNA, M., KUCHARČÍK, L., SLÁDEK, A. (2013). Complex evaluation of porosity in A356 aluminium alloy using advanced porosity module. In Manufacturing Technology, Vol. 13, No. 1, p. 26-30

[11] ROUČKA, J. (2004). Metallurgy of Non-ferrous alloys. Brno. 1. Edition. 1. Edition. VUT Brno, 2004, 148p. ISBN 80-214-2790-6.

[12] CAMPBELL, J. (2003). Castings. Vol. 2, Butterworth - Heinemann, Oxford, pp. 242 - 255. ISBN 9780750647908. 